\title{
The home stretch
}

\section{The leading US presidential candidates are not trying to woo} voters with science issues. But the senator who wins will help shape the world's most influential research agenda. Alexandra Witze looks at how John McCain and Barack Obama have developed their thoughts on science and technology, and where each of them might take the country if elected.

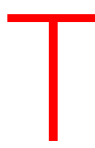

he United States' scientific establishment has been doing its best to get this year's presidential contenders to pay attention to it. In April, a group of supporters calling itself Science Debate 2008 reserved a large hall at the Franklin Institute in Philadelphia, hoping the whole field of candidates would show up to take questions. None accepted. In fact, it took evangelical pastor Rick Warren to get the two leading candidates Republican John McCain and Democrat Barack Obama - together for the first time, at a forum at a California church in August.

\section{EDITORIAL \\ $431 \quad$ America's fresh start \\ SPECIAL FOCUS \\ 442 The home stretch \\ Alexandra Witze}

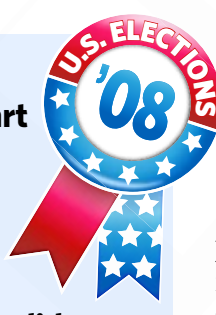

446 Questioning the candidates

451 Agencies of change

Eric Hand, Meredith Wadman, Jeff Tollefson

\section{COLUMN}

453 Not the best advice

David Goldston

\section{BOOKS \& ARTS}

464 Science books for the next president

Steven Shapin, Jerry Coyne, Rita Colwell, Martin Nowak, Jerry Ravetz, Kevin Padian

\section{PODCASTS}

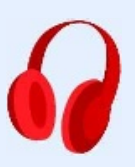

\section{Policy roundtables on:}

- Energy and climate

- Biomedical research

- Economic competitiveness

For our election podcasts and more online content, see www.nature.com/uselection.
It is no surprise that the campaign has revolved more around the war and the economy, and of course personality, than science. It would be a mistake, however, to assume that neither McCain nor Obama cares about science and technology. In fact, both have a long history of engaging with core science issues - from McCain running a Senate committee that oversaw science, among many topics, to Obama working on technological approaches to fighting poverty. During the course of the campaign both candidates have laid out where they stand on scientific and technical issues (see page 446).

Major changes are in store no matter who wins. Many scientists argue that the research environment will be better off during the next four years than it has been under President George W. Bush's two terms. The next president will probably play a leading part in initiating the first mandatory greenhouse-gas regulations in the United States. He may also lift the restrictions on research with human embryonic stem cells that limit federal funding to cell lines that are at least seven years old. New people will move into critical positions such as the presidential science adviser (see page 453) and heads of the various science-related agencies (see page 451). This will be a breath of fresh air to researchers who charge that the Bush administration has manipulated science to political ends, from climate-change reports to endangered-species listings.

Bush aside, though, the question remains as to how McCain or Obama might influence research. What the candidates say about science will normally be broad-brush; no one expects a president to rattle off details of the confinement of quarks or the dynamics of proteins. More pertinent is how they think about science as a process, where they get their scientific advice from - and how they might incorporate such advice into where they would lead the country.

Obama's views on how science and technology affect the nation's growth trace back several years. Working with disadvantaged children

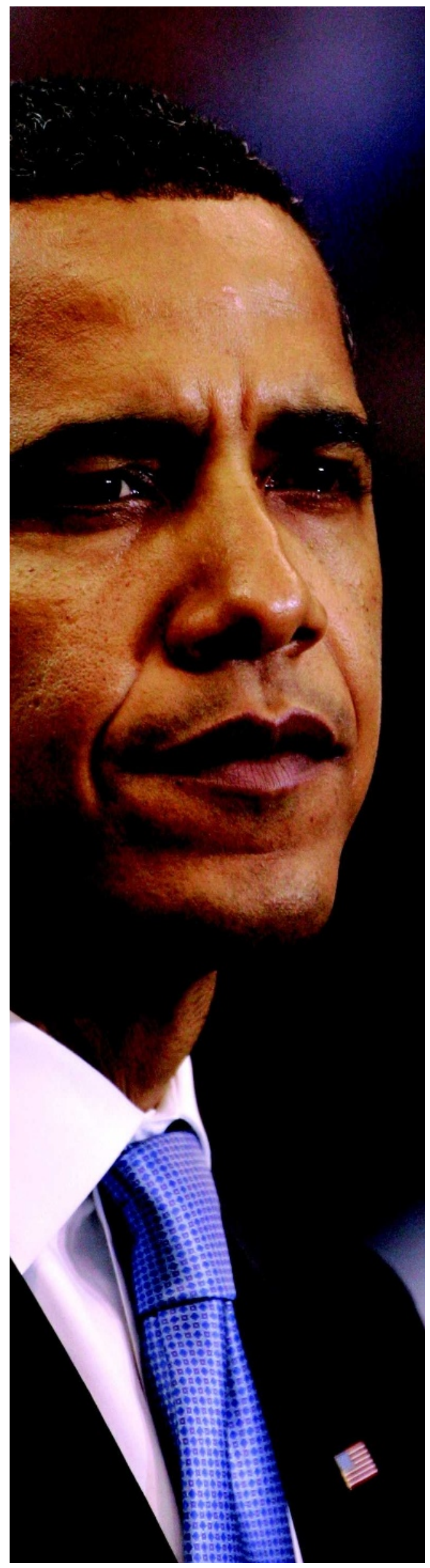




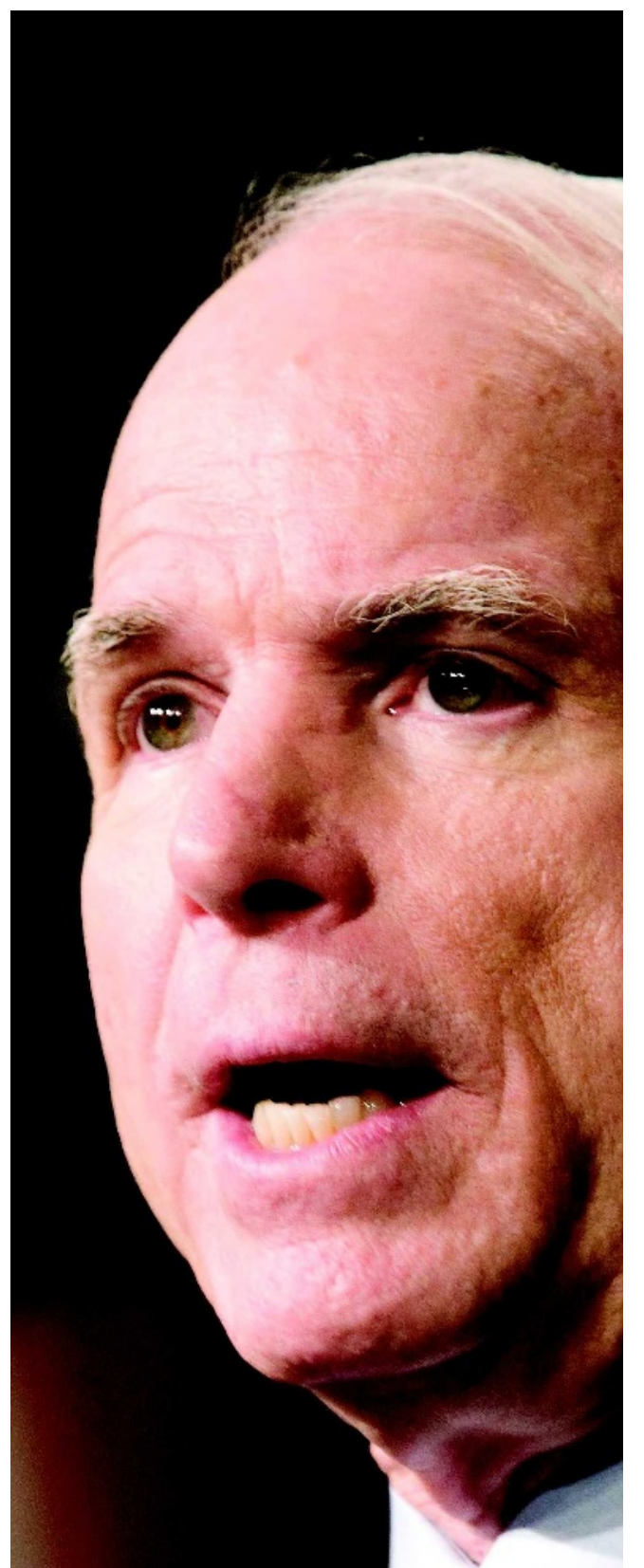

on Chicago's South Side, "he saw the role and importance of technology in the future of those schoolchildren", says Alec Ross, a technology entrepreneur and campaign adviser. Early in his campaign, Obama released details on how he would expand broadband access as a way to shrink the 'digital divide' between rich and poor, and described plans to appoint the first-ever national 'chief technology officer' to improve infrastructure.

The theme of how technology investment can drive economic growth comes up again and again in Obama's speeches. His advisers say that he spends a lot of time thinking about how science and technology can be used to address specific national aims, such as health care and climate change. To this end, Obama voted in the Senate in favour of the 2007 America COMPETES Act, which authorized among other things a doubling in the physical-sciences research budgets at the National Science Foundation, the Department of Energy's Office of Science and the National Institute of Standards and Technology. It was a politically popular act that sailed through the Senate - also garnering McCain's support - perhaps because it was simply an expression of support for funding in these areas and not an actual allocation of dollars.

\section{Expert advice}

Much of Obama's advice on economic matters comes from a group of advisers that includes Austan Goolsbee of the University of Chicago in Illinois. Obama also maintains a select group of science advisers headed by Nobel laureate Harold Varmus, head of the Memorial Sloan-Kettering Cancer Center in New York and former director of the National Institutes of Health. Varmus endorsed Obama back in February and has been his linchpin for science advice since; even so, the most face time Varmus has had with the candidate was a two-hour summit on competitiveness issues at Carnegie Mellon University, in Pittsburgh, Pennsylvania, in June.

Varmus has strong local support in Don Lamb, an astrophysicist at the University of Chicago who has known Obama since he represented Lamb in the state senate of Illinois. Lamb serves as a sort of secretary for the advisory group, maintaining e-mail lists and helping coordinate discussions and the flow of advice back into the Obama campaign. Other members of the team include Henry Kelly, president of the Federation of American Scientists in Washington DC, who served as assistant director for technology in Bill Clinton's advisory office; Gil Omenn, a professor of internal medicine and human genetics at the University of Michigan in Ann Arbor who held several key policy positions in the Carter administration; and Sharon Long, a biologist 고 at Stanford University in Palo Alto, California. Also loosely connected are a host of Nobel laureates including Bob Horvitz of the Massachusetts Institute of Technology; Peter Agre of the Johns Hopkins Malaria Research Institute in Baltimore, Maryland; and Burton Richter of the Stanford Linear Accelerator Center in Menlo Park, California. The team also includes Tom Kalil, special assistant to the chancellor for science and technology at the University of California, Berkeley, and deputy assistant to President Clinton for technology and economic policy. Kalil was the main architect of Hillary Clinton's science platform, generally regarded as the most well-developed set of policies on science for any of the presidential candidates until she dropped out of the race.

Varmus's team helps to write material that serves as the basis for developing policy platforms, and otherwise throws general science advice into the churning maw that is any candidate's advisory system. A related group funnels climate and energy advice up the same chain. This group includes energy researcher Dan Kammen of the University of California, Berkeley, and energy policy expert Jason Grumet, founder and president of the Bipartisan Policy Center in Washington DC.

Academics are notoriously left-leaning - a national study done last year by sociologists Neil Gross, from Harvard University in Cambridge, Massachusetts, and Solon Simmons, from George Mason University in Fairfax, Virginia, found that half of them identified themselves as Democrats, and just $14 \%$ as Republicans. So perhaps it's not surprising that McCain's science and technical advice comes more from corporate and political leaders than from the academic world. Much of his campaign's day-to-day work on technical matters comes from experienced staff members who have worked with McCain for years. These include Floyd DesChamps of the Senate Committee on Commerce, Science and Transportation, which McCain headed for much of the time between 1997 and 2001. The committee has a broad remit but includes, for instance, NASA, where McCain was involved in following up on the 2003 Columbia spaceshuttle disaster. Other technical advice to the McCain campaign comes from business leaders such as Carly Fiorina, the former chief executive of Hewlett-Packard, and Meg Whitman, the former chief executive of eBay.

McCain's most detailed positions on science issues come in the field of energy. According to James Woolsey, director of central intelligence under Bill Clinton, the campaign's top policy advisers request specific advice on energy from a small group that includes Woolsey; Ronald Reagan's national security adviser Robert McFarlane (now a renewable-energy 

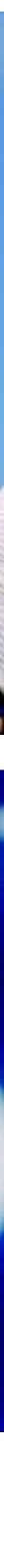

advocate); and James Schlesinger, secretary of defence under Richard Nixon and Gerald Ford and secretary of energy under Jimmy Carter. Since July, the McCain campaign has also relied on chief strategist Steve Schmidt - an adviser to former White House deputy chief of staff Karl Rove and to Vice-President Dick Cheney - who helped develop energy and climate policies when he masterminded the successful 2006 re-election campaign of California governor Arnold Schwarzenegger.

Environmental groups have not been big fans of McCain in recent years - yet in some respects, McCain has adopted politically risky energy policies. He has proposed scrapping subsidies and tariffs for biofuels, an approach favoured by Obama that plays well with voters in America's corn-growing heartland, but that a growing consensus among energy and environmental experts rejects. Most strikingly, McCain is a long-time supporter of a cap-andtrade approach to regulating greenhouse-gas emissions, in which the government sets an overall cap on pollution and then issues permits to each polluter; those that reduce their emissions cheaply can sell the extra permits to anybody who needs them. Whereas McCain's plan for such a system would distribute the allowances and allow businesses to sell any unused emissions for cash, Obama's version of the scheme would auction off the allowances from the start. Obama has also pledged $\$ 150$ billion over the next ten years towards energy technologies.

\section{Environmental back-up}

Five years ago, McCain introduced the first version of a significant emissions-regulating bill with Joseph Lieberman, the formerly Democratic, now Independent, senator from Connecticut. Introduced three times into the Senate, the McCain-Lieberman bill never garnered enough votes to pass, but is seen as the prototype and inspiration for much of what

followed. Tim Profeta, the former Lieberman staff member who worked with McCain aides to write the bill, says he thinks McCain will continue to fight for a cap-and-trade strategy if elected as president. "He may have to make some deals, but I don't see any indication from him that he really is wavering in his dedication to the topic. At this point, I have to take him at his word," says Profeta, now director of the Nicholas School of the Environment at Duke University in Durham, North Carolina.

If the presidential candidates' views on scientific matters are of only minor interest to voters, those of the vice-presidential candidates are usually even less so. This year, though, that might not hold true. Obama's choice of Joe Biden had much more to do with Biden's experience in foreign policy than anything he might have to say about offshore oil drilling. Biden, a senator from Delaware, hews to traditional Democratic lines on most technical issues. Despite his personal belief that human lives begin at conception, Biden supports abortion rights and human embryonic stem-cell research. Biden has never been shy about speaking his mind; in an appearance last month on 
